\title{
Menumbuhkan kesadaran anak terhadap pentingnya penerapan protokol kesehatan di masa kenormalan baru
}

\author{
Dwi Ulfah Nurdahliaa,1, Siti Zazak Sorayab,2*, Rosyid Nihru Mas'ulc,3 \\ a,b,cInstitut Agama Islam Negeri, Ponorogo \\ 1dwiulfa@iainponorogo.ac.id; *2zazak@iainponorogo.ac.id; 3nihrurosyid@gmail.com \\ *Correspondent Author
}

KATAKUNCI

anak;

kesadaran;

masa kenormalan baru; protokol kesehatan

\section{ABSTRAK}

Pandemi Covid-19 saat ini menimbulkan banyak tekanan, tak terkecuali pada anak. Anak menjadi salah satu kelompok yang rentan terinfeksi Covid-19. Oleh karena itu, untuk memutus rantai penyebaran virus, perlu adanya sosialisasi dan edukasi yang tepat bagi anak dalam pencegahan Covid-19. Penelitian ini bertujuan untuk mengetahui pengetahuan anak mengenai Covid-19 serta tindakan preventif yang dilakukan agar terhindar dari virus tersebut di masa kenormalan baru. Metode penelitian yang dilakukan yaitu kualitatif dengan pendekatan fenomenologi. Partisipan yang terlibat dalam penelitian ini sejumlah 15 anak yang berdomisili di Dolopo, Madiun dengan menggunakan teknik purposif. Data dikumpulkan melalui wawancara, observasi, dan field notes. Hasil penelitian menunjukkan bahwa anak-anak telah memiliki pemahaman mengenai Covid-19 sebagai virus yang berbahaya dan mematikan. Informasi tersebut diperoleh dari orang-orang sekitar, seperti: orang tua, guru, kakek, nenek, serta media televisi. Selain itu, anak-anak juga mampu melakukan tindakan pencegahan virus, seperti: rajin mencuci tangan, menggunakan masker, menjaga jarak, tidak keluar rumah, serta berjemur. Dengan demikian dapat disimpulkan bahwasanya anak-anak sudah cukup memiliki kesadaran dalam memproteksi diri serta menerapkan protokol kesehatan di masa kenormalan baru yang disertai dengan dukungan dari seluruh pihak.

\section{Raising children's awareness of the importance of implementing health protocols in the new normal period}

\section{KEYWORDS}

awareness;

children;

health protocol;

new normal era
The Covid-19 pandemic is currently causing a lot of pressure, including on children. The children become one of the groups that are vulnerable to get infected with Covid-19. To break the chain of spreading the virus, it is necessary to raise awareness about protection measures against Covid-19. This study aimed to explore children's understanding of Covid-19 and to find out the ways of preventing the spread of Covid-19 in the New Normal Era. The research method used in this research was qualitative with a phenomenology approach. The participant was 15 children as participants who live in Dolopo, Madiun used purposive sampling. The data were gathered through interviews, observations, and field notes. The results showed that all of the children had an understanding of Covid-19 as a dangerous and deadly virus. This information was obtained from people around them, such as parents, teachers, grandparents, and television media. Also, children can take action of virus prevention measures, such as wash hands frequently with soap and running water, wearing masks, keeping a safe distance, 
staying at home, and sunbathing. Therefore, it can be concluded that children have enough awareness to protect themselves and implement health protocols during this New Normal Era with support from the people around them.

This is an open-access article under the CC-BY-SA license.

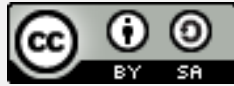

\section{Pendahuluan}

Pandemi Covid-19 menyebar di 121 negara, info ini dilansir dari berita kompas.com yang diawali dengan adanya kasus pneumonia di Wuhan, namun pada saat itu belum ada data yang terinfeksi di Indonesia. Sampai pada akhirnya 2 Maret 2020, pemerintah mengumumkan terdapat dua WNI positif terpapar Corona virus. Sejak ditemukannya kasus covid di Indonesia, pada saat itu pemerintah mulai beraksi dan berusaha melakukan langkah-langkah pemutusan rantai penularan Covid-19. Suasana di Indonesia, mulai tampak menakutkan dengan bertambahnya pasien dan beberapa dokter yang pada akhirnya menjadi korban (Kompas Online, 2020). Berita tentang Covid-19 pun mulai muncul di media, bahkan status whatsapp dan group whatsapp pun banyak memberitakan perkembangan Covid-19 di Indonesai. Pemberitaan ataupun beredarnya berita Covid-19 seolah menjadi informasi penting bagi masyarakat untuk terus meng-update berita. Termasuk peneliti yang juga mengupdate berita baik dari televisi atau media elektronik lainnya sepperti handphone. Pemberitaan Covid-19 pun semakin gencar, hal ini mungkin bertujuan masyarakat lebih berhati-hati.

Beberapa tindakan dilakukan oleh pemerintah pusat maupun pemerintah daerah untuk melindungi masyarakatnya. Meski pemerintah Indonesia sempat dianggap lalai dan lambat dalam menangani kasus tersebut, namun selanjutnya strategi pemutusan rantai penularan Covid-19 berangsur teroganisir. Hal ini dimulai dari penutupan akses di beberapa wilayah, yang berimbas pada penon-aktifan transportasi umum. Proses pemutusan rantai ini juga berdampak pada dunia pendidikan dan dunia kerja yang akhirnya dilakukan dari rumah melalui media daring yang dikenal dengan istiah school from home dan work from home.

Penelitian ini lebih difokuskan pada menumbuhkan kesadaran anak terhadap pentingnya penerapan protokol kesehatan di masa kenormalan baru yang merupakan suatu keharusan. Hal ini berdasar dari kasus Covid-19 yang mulai menyerang anak-anak, seperti yang dilansir dari laman Kompas, 5 Juni 2020 (Afifah, 2020) yang menyatakan bahwa virus Corona dapat menjangkiti siapa saja, tak terkecuali anak-anak. Jika anak-anak juga rentan terserang Covid-19, maka sangat penting untuk menumbuhkan kesadaran pada anak-anak tentang pentingnya menjaga diri mereka dengan melakukan protokol kesehatan.

Menumbuhkan kesadaran pada anak-anak untuk melakukan protokol kesehatan merupakan suatu yang mungkin sulit untuk dilakukan. Hal ini, dikarenakan anak-anak memiliki kecenderungan untuk melakukan sesuatu sesuai kebiasaan yang dilakukannya atau yang sudah menjadi habit dalam kesehariannya. Sementara pada era kenormalan baru, anak cenderung dituntut untuk mengikuti kebiasaan baru. Hal ini menjadi fenomena yang menarik untuk dikaji, dalam rangka mengetahui faktor yang berpengaruh terhadap penumbuhan kesadaran anak terhadap pentingnya penerapan protokol kesehatan. Seperti halnya pembiasaan perilaku baru pada anak yang juga dipengaruhi oleh interaksi sosial dalam aktivitas kenormalan baru.

Penelitian ini dilatarbelakangi adanya ketertarikan peneliti pada penyebaran informasi yang akhir-akhir ini banyak dipertanyakan keabsahannya. Apakah informasi yang disampaikan mampu menembus anak-anak yang pada dasarnya secara konseptual atau 
pemahaman tentang virus belum tentu memahami. Sementara pemahaman terhadap sesuatu merupakan suatu hal yang berkaitan dengan bagaimana pengetahuan individu dan terkait dengan kognitif individu. Seperti halnya teori perkembangan kognitif menurut teori Piaget (Santrock, 2007), menyatakan bahwa anak secara aktif membangun pemahaman mengenai dunia melalui empat tahap perkembangan kognitif. Dua proses yang mendasari perkembangan tersebut adalah organisasi dan adaptasi. Artinya, untuk memahami dunia maka manusia dapat mengorganisasikan pengalaman-pengalamannya. Pernyataan Piaget (dalam Santrock, 2007) menunjukkan bahwa setiap individu akan melakukan pengamatan terhadap situasi yang sedang terjadi di sekitar mereka dan akan mengorganisasikan dengan pengalaman-pengalaman untuk dapat disesuaikan atau diadaptasi dengan pemikiran yang individu miliki.

Piaget (dalam Santrock, 2007), juga mempercayai bahwa individu melakukan adaptasi melalui dua cara yaitu: asimilasi dan akomodasi. Berikut penjelasan asimilasi dan akomodasi menurut Piaget yaitu,

1. Asimilasi terjadi saat anak menggabungkan informasi ke dalam pengetahuan yang telah mereka miliki. Proses pengetahuan yang terjadi pada anak-anak pun terjadi dengan penggabungan informasi yang diterimanya. Melalui indera yang anak-anak miliki, maka informasi akan terserap secara otomatis untuk mereka gabungkan dengan pengetahuan yang mereka miliki sebelumnya.

2. Akomodasi terjadi bila anak menyesuaikan pengetahuan mereka agar cocok dengan informasi dan pengalaman baru. Proses akomodasi akan membantu anak-anak untuk bertindak sesuai dengan pengetahuan barunya untuk bertindak secara tepat.

Proses asimilasi dan akomodasi menjadi bagian terpenting untuk anak-anak dalam menghadapi masa kenormalan baru. Oleh karena itu, anak-anak diharap mendapatkan informasi dari lingkungan secara tepat tentang bahaya Covid-19 dan mampu bertindak sesuai dengan standar lingkungan, yaitu bagaimana menerapkan protokol kesehatan dalam aktivitas keseharian. Sesuai dengan yang disampaikan dalam jurnal yang ditulis oleh Rahardjo (2020), yang melakukan penelitian kepada mahasiswa. Adapun hasil penelitiannya menjelaskan bahwa informasi yang beredar dalam hal ini terkait social media fatige memberikan efek pada beban kognitif mahasiswa. Hal ini terjadi dimungkinkan karena mahasiswa sudah memiliki konsep jelas terhadap informasi berupa berita yang diterimanya. Namun, bagaimana dengan anak-anak yang berada pada masa gencarnya informasi di tengah pandemi dan bagaimana menumbuhkan kesadaran pada diri mereka dalam penerapan protokol kesehatan di masa kenormalan baru terkait dengan pemahaman anak yang relatif berbeda dengan usia remaja dalam hal ini mahasiswa.

Tujuan dari penelitian ini adalah menjelaskan bagaimana membentuk kesadaran pada anak tentang pentingnya melakukan protokol kesehatan, serta menjelaskan bagaimana pemahaman anak-anak tentang Covid-19 atau Corona. Hal ini dikarenakan pemahaman yang benar tantang Covid-19 akan mempermudah anak untuk mampu dikendalikan atau menumbuhkan kebiasaan untuk melaksanakan protokol kesehatan pada masa new normal. Dengan demikian, diharapkan hasil penelitian ini memiliki manfaat sebagai referensi bagi penelitian berikutnya yang mungkin dikaitkan dengan bagaimana perkembangan anak-anak selama new normal terkait motivasinya dalam belajar atau pun kreativitas yang dimiliki, termasuk bagaimana kelekatan yang terbangun dalam keluarga selama pandemi Covid-19.

\section{Metode}

Penelitian ini dilakukan dengan pendekatan kualitatif. Hal ini dikarenakan penelitian bertujuan untuk memahami dan mengeksplorasi tiap makna dari setiap individu maupun dari masalah sosial atau kemanusiaan (Creswell, 2014). Pendekatan yang dilakukan yaitu fenomenologi. Menurut Watt dan Berg (1995), fenomenologi berupaya mengkaji tentang 
bagaimana orang melakukan sebuah pengalaman serta makna pengalaman itu bagi dirinya. Oleh karena itu, untuk melakukan penyelidikan yang komprehensif, sistematis, serta rinci mengenai kesadaran anak terhadap pentingnya penerapan protokol kesehatan di Masa Kenormalan Baru maka teknik sampling yang digunakan untuk menjaring partisipan pada penelitian ini menggunakan purposive sampling, dimana teknik pengambilan sampel dengan pertimbangan tertentu (Sugiyono, 2009). Adapun kriteria populasi penelitian ini yaitu anak laki-laki dan perempuan dengan rentang usia 4-7 tahun yang tinggal di wilayah Dolopo, Madiun. Berdasarkan karakteristik populasi, terpilih 15 anak yang dapat dijadikan partisipan.

Metode pengumpulan data dilakukan melalui wawancara, observasi, serta catatan lapangan (field notes). Sebelum melakukan wawancara, peneliti meminta kesediaan orang tua dalam rangka meminta izin untuk melakukan wawancara kepada anak-anak mereka untuk diteliti. Wawancara dilakukan untuk memperoleh informasi yang mendalam antara peneliti dan partisipan mengenai topik yang diteliti. Peneliti menggunakan wawancara semi-struktur agar partisipan dapat mengungkapkan pemikiran dan opini mereka tanpa paksaan. Selain itu, peneliti juga sangat menjaga mood partisipan selama wawancara dikarenakan partisipan penelitian masih berada di usia anak. Proses wawancara berlangsung lebih kurang 1 jam dengan menyesuaikan kondisi masing-masing partisipan. Selain itu, observasi yang dilakukan yakni observasi non-partisipan, dimana observer tidak terlibat dalam kehidupan observee. Catatan lapangan (field notes) juga dilakukan untuk menulis yang terucap, terlihat, terdengar serta dialami selama proses penelitian (Moleong, 2017). Adapun catatan lapangan diperoleh dari hasil transkrip wawancara serta refleksi observasi.

Teknik analisis yang digunakan yakni model analisis Spradley. Ada empat tahapan analisis yang dikemukakan Spradley (1980) dalam analisis data penelitian kualitatif, yaitu analisis domain, taksonomi, komponen, dan tema. Selanjutnya, untuk menguji kredibilitas data, dilakukan triangulasi (Moleong, 2017). Triangulasi metode dilakukan dalam penelitian ini dengan cara pengumpulan data ganda berupa data observasi dan data wawancara sebagai data pembanding.

\section{Hasil}

Berdasar hasil pengumpulan data maka diperoleh hasil yang positif tentang pemahaman anak terkait dengan virus Corona. Hasil penelitian menunjukkan anak-anak dapat memahami tentang virus Corona dan bahaya dari virus Corona. Selain itu, anak-anak juga memahami bagaimana cara melindungi dirinya. Hasil penelitian juga menunjukkan bahwa informasi tentang bahaya virus Corona mampu tersampaikan pada anak-anak melalui media atau perantara yaitu orang tua dan guru. Berikut indikator anak-anak memahami infomasi tentang Covid-19 atau virus Corona:

1. Mampu menjelaskan apa yang dimaksud dengan virus Corona, meski dengan menggunakan kata dan kalimat yang sederhana, saat ditanya apa kamu tahu virus Corona? anak-anak menjawab dengan singkatan pendek, dengan ucapan "iya tahu". Anak memahami virus Corona sebagai virus yang mematikan, dan juga penyakit.

2. Mampu menggambarkan virus Corona sesuai dengan kemampuan anak. Anak menggambarkan dengan sederhana seperti membentuk sebuah lingkaran yang seperti di tusuk jarum.

3. Cara menghindari virus Corona. Anak mampu menyebutkan satu hingga beberapa beberapa cara menghindari virus Corona, seperti berada di rumah, tidak boleh keluar rumah, mencuci tangan, mencuci tangan pakai sabun, memakai masker, menjaga jarak, menjaga kebersihan, tidak pergi ke tempat umum. Berdasarkan hasil penelitian menunjukan anak mampu memberikan informasi terkait cara menghindari virus Corona melalui jawaban singkat yang diberikan oleh mereka.

Berdasar hasil dari penelitian di lapangan yang dilakukan pada 15 orang anak, menunjukkan bahwa anak memiliki pengetahuan tentang bahaya virus dan mereka telah mendapatkan informasi tentang bagaimana cara menghindari virus Corona. Tiga indikator 
pemahaman anak tersebut merupakan modal dasar untuk menumbuhkan kesadaran anak terhadap pentingnya penerapan protokol kesehatan dimasa kenormalan baru. Kesadaran anak terkait penerapan protokol kesehatan diharapkan mampu memberikan sumbangsih dalam penurunan kasus Covid-19 yang memerlukan dukungan dari seluruh komponen masyarakat. Menumbuhkan kesadaran pada anak merupakan bentuk dan upaya langkah preventif dalam rangka menjaga kesehatan diri di era new normal. Hal ini dikarenakan era new normal memaksa seluruh kalangan masyarakat untuk mampu beradaptasi di tengah pandemik, mampu tetap produktif sehingga adakalanya harus beraktivitas di luar rumah. Kondisi tersebut tentu saja termasuk mempengaruhi aktivitas anak-anak, yang mana adakalanya mereka juga akan ikut beraktivitas di luar rumah.

Hasil penelitian juga menunjukan anak mampu untuk mengasimilasi setiap informasi yang diperoleh dari orang-orang di sekitar, seperti dari orang tua, guru, ataupun dari orangorang terdekat mereka yang memberikan informasi tentang Covid-19, beserta bahayanya. Anak-anak juga mendapatkan update informasi/berita Covid-19 melalui media elektronik yaitu televisi. Berbekal dari pengetahuan yang anak miliki, hal ini mempermudah anak untuk beradaptasi di masa pandemi dengan cara:

1. Tetap berada di rumah/ tidak keluar rumah/ tidak keluar ke tempat umum. Perilaku anak cenderung mengurangi diri untuk keluar rumah muncul akibat intervensi dari orang tua.

2. Mencuci tangan/ mencuci tangan menggunakan sabun. Kegiatan ini merupakan suatu kebiasaan yang dilakukan anak-anak, terutama saat mereka berada di luar rumah.

3. Sekolah di rumah. Proses pembelajaran tidak dilakukan di sekolah, melainkan dengan SFH (school from home), sehingga tidak membentuk kerumunan.

4. Berjemur/ berpanas-panasan. Anak berada di luar rumah, tepatnya di depan rumah untuk terkena sinar matahari.

5. Membunuh/ mematikan virus. Pada bagian ini, anak memang belum mampu menjelaskan secara logis apa yang dimaksud. Anak hanya menyebutkan bahwa virus harus dibunuh supaya tidak mengganggu manusia.

6. Memakai masker. Penggunaan masker menjadi suatu kewajiban pada saat mereka keluar rumah untuk waktu yang cukup lama.

7. Menjaga jarak. Anak melakukan dengan cara mengurangi intensitas bermain, dan orang tua dalam hal ini menjadi pengingat, karena anak-anak masih memiliki keinginan untuk bermain dengan teman lainnya.

Berdasar dari 7 (tujuh) pengetahuan anak-anak tentang adaptasi yang harus mereka lakukan, menunjukan bahwa anak masih memerlukan pendampingan orang tua dan orangorang di sekitarnya. Tujuannya adalah untuk terus mengingatkan dan mendampingi anak agar benar-benar melakukan atau menjalankan segala kegiatan mereka sesuai protokol kesehatan.

\section{Pembahasan}

Setiap individu diciptakan memiliki kepekaan terhadap kondisi lingkungan dan beradaptasi dengan lingkungan dimana mereka berada. Hal ini di dalam bidang psikologi dikenal dengan istilah resiliensi. Resiliensi merupakan suatu kemampuan yang dimiliki individu untuk menghadapi dan mengatasi kesulitan dalam hidup dengan cara yang adaptif, serta mampu belajar dari hal tersebut sekaligus beradaptasi di dalam kondisi yang sulit tersebut (Nisa, 2016). Berdasar pengertian tersebut, maka ada beberapa poin yang dapat ditumbuhkan pada anak, yaitu: mampu belajar menghadapi dan mengatasi kesulitan dengan cara adaptif, serta mampu belajar sekaligus beradaptasi dalam kondisi yang sulit. Tujuannya adalah agar anak dapat melakukan perubahan suatu kondisi, dan pastinya dalam perubahan tersebut membutuhkan sebuah proses untuk mampu mengikuti kebaruan dalam suatu 
aktivitas.

Masa kanak-kanak adalah masa pencarian informasi, anak akan belajar tentang apa yang diharapkannya dari dunia dan apa yang dunia harapkan kepadanya (Prianti, 2011). Pernyataan tersebut sesuai dengan kondisi anak-anak saat menghadapi kenormalan baru. Anak-anak tentunya memiliki rasa penasaran dengan kebiasaan-kebiasaan yang berubah di masa kenormalan baru, sehingga mereka cenderung bertanya untuk mendapatkan informasi. Proses pencarian informasi mereka lakukan dengan bertanya kepada orang-orang yang berada di sekitarnya, atau secara aktif mendapatkannya melalui media telivisi. Melalui rasa penasaran yang dan direalisasikan anak dalam bentuk pertanyaan yang disampaikan, harapannya adalah anak dapat memperoleh informasi dan paham tentang apa yang harus mereka lakukan dalam menghadapi masa kenormalan baru.

Semua informasi yang anak peroleh akan diporses dalam kognitif mereka yaitu, adanya proses asimilasi yang diikuti dengan proses adaptasi dalam menghadapi masa kenormalan baru. Secara sederhana dapat digambarkan dalam gambar 1 berikut ini:

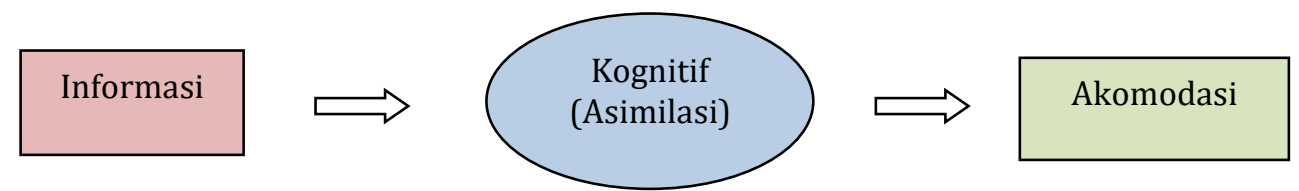

Gambar 1. Alur Proses Pemahaman Informasi

Berikut penjelasan gambar alur proses pemahaman informasi yang akan membantu anak-anak dalam menumbuhkan kesadaran pentingnya protocol kesehatan dalam menghadapi kenormalan baru:

1. Informasi, yaitu anak-anak akan menerima informasi yang berasal dari orang-orang yang berada disekitarnya. Dimana informasi ini merupakan bahan dasar untuk memberikan pengetahuan baru terkaid dengan Covid-19, dan pentingnya melakukan protokol kesehatan dalam masa menghadapi kenormalan baru.

2. Kognitif yang diikuti dengan proses asimilasi, yaitu anak-anak memperoleh informasi yang akan dikelola dalam kognisi mereka, dan selama penerimaan informasi ini proses asimilasi pun berlangsung, yaitu anak-anak mulai menggabungkan informasi yang diperoleh untuk mampu dirasionalisasi. Anak-anak mengalami proses berpikir, yaitu proses yang melibatkan beberapa manipulasi pengetahuan dalam sistem kognitif. Hal ini sama halnya dengan ketika pemain catur sedang merenungkan gerakan, memori masa lalu berkombinasi dengan informasi masa sekarang untuk mengubah pengetahuannya akan situasi (Solso, 2008). Proses berpikir yang dialami oleh anak-anak akan membawa anak-anak pada pemahaman informasi yang diperolehnya.

3. Akomodasi, yaitu anak menyesuaikan pengetahuan mereka agar sesuai dengan informasi dan pengalaman baru. Proses akomodasi akan membantu anak-anak untuk bertindak sesuai dengan pengetahuan barunya. Selanjutnya, ketepatan dalam bertindak tentunya memerlukan penguatan dari lingkungan hingga dapat menjadi kebiasaan untuk melakukan protokol kesehatan menghadapi keormalan baru.

Hasil penelitian menunjukkan bahwa anak-anak memiliki pemahaman tentang virus Corona seperti yang telah diuraikan pada hasil penelitian. Selain itu, anak-anak telah memiliki kemampuan untuk menjaga diri di tengah pandemi, dan berikutnya mereka harus beradaptasi dengan era new normal. Pemahaman anak-anak terkait virus Corona menjadi modal untuk menumbuhkan kesadaran anak terhadap pentingnya penerapan protokal kesehatan di masa kenormalan baru, sebagai wujud langkah preventif menjaga kesehatan diri di era new normal. Berikut akan diuraikan bagaimana cara menumbuhkan kesadaran anak dengan pemahaman anak-anak yang menjadi modal utama saat menghadapi masa kenormlan baru: 
1. Menghadapi dan mengatasi kesulitan dengan cara adaptif

Individu dilahirkan untuk menjadi makhluk yang adaptif, melalui dukungan kelurga yang terdiri dari orang tua, dukungan dari lingkungan pendidikan yaitu bapak dan ibu guru di sekolah, serta lingkungan masyarakat yang diwakili oleh media elektronik televisi, maka anak akan memperoleh informasi yang tepat.

a. Orang tua

Orang tua dapat menumbuhkan pemahaman kesadaran pentingnya melakukan protokol kesehatan saat anak berada di rumah dengan cara melatih anak melakukan kebiasaan menjaga kebersihan diri dan lingkungan rumah. Tentunya ini akan menjadi tantangan tersendiri bagi orang tua untuk membentuk suatu kebiasaan pada anak, dan akan terus menjadi kebiasaan dimanapun mereka berada. Seperti penelitian yang dilakukan di Malaysia, anak-anak terkadang sulit untuk menekan keinginan untuk memakan sesuatu yang sebenarnya mereka sudah tahu bahwa makanan tersebut tidak sehat (Hoque, Kamaluddin, Razak, \& Wahid, 2016). Hal inilah yang menjadi tantangan orang tua, bagaimana anak harus mampu menahan diri untuk tetap makan makanan yang sehat supaya daya tahan tubuhnya tetap baik dan dapat terhindar dari virus Corona. Pembentukan kebiasaan ini tentunya harus dilatihkan setiap hari dan dilakukan secara berulang. Sebab, pada prinsipnya ketika anak mendapat peringatan berulang berupa informasi, maka akan tumbuh sebuah persepi dan menjadi konsep untuk hidup sehat. Dengan demikian, orang tua akan berhasil membentuk konsep protokol kesehatan yang harus dilakukan selama masa kenormalan baru. Keberhasilan ini akan tampak dari anak-anak yang mampu menyebutkan perihal seperti harus cuci tangan, memakai masker, dan menjaga jarak.

b. Bapak dan ibu guru

Bapak dan ibu guru dapat turut andil menumbuhkan kesadaran pentingnya penerapan protokol kesehatan ketika anak-anak berada di sekolah. Tentunya hal ini, sudah dilakukan oleh pihak sekolah yaitu melaksanakan proses kegiatan belajar mengajar dengan tetap menjalankan protokol kesehatan demi memutus penyebaran Covid-19. Pihak sekolah menjadi lebih mudah dalam mengontrol peserta didik dan menguatkan pemahaman positif yang dimiliki anak-anak untuk tetap menjaga jarak, mencuci tangan memakai sabun, dan menggunakan masker. Tentu saja hal ini membutuhkan pengulangan, karena harus dilakukan secara konsisten. Bahwa pembiasaan dalam psikologi dikenal dengan teori operant conditioning atau metode pembiasaan yaitu salah satu metode yang tepat dalam membentuk disiplin anak (ihsani, Kurnia, Suprapti, 2018). Jika dikaitkan dengan hasil penelitian tentang menumbuhkan kesadaran penerapan protokol kesehatan, maka hal ini dilakukan pada anak melalui pembiasaan disiplin dalam melakukan protokol kesehatan selama masa kenormalan baru.

c. Masyarakat

Masyarakat memiliki peranan penting dalam menumbuhkan kesadaran anakanak tentang pentingnya protokol kesehatan. Masyarakat di sini adalah, mereka yang berada di lingkungan tempat tinggal anak. Berdasarkan hasil wawancara dan observasi di lapangan terlihat aktivitas di lingkungan sekitar anak tidak seperti sebelum ada pandemi Covid-19. Anak-anak, lebih banyak dirumah dan anak-anak juga telah memiliki pemahaman sederhana tentang Covid-19, maka secara tidak langsung memberikan informasi bahwa masyarakat juga memahami dan mendukung penerapan protokol kesehatan di masa kenormalan baru.

2. Mampu belajar sekaligus beradaptasi dalam kondisi yang sulit

Anak-anak merupakan sosok individu yang secara fitrah memiliki rasa keingintahuan yang tinggi. Mereka juga memiliki keinginan untuk melakukan segala sesuatu yang 
menyenangkan, seperti bermain dan berkumpul dengan teman-temannya. Dan tentu saja, kondisi new normal akan berdampak pada pembatasan ruang gerak anak-anak. Oleh karena itu, jika tidak diatasi maka situasi tersebut akan menjadi tekanan bagi anak-anak. Meski pada kenyataannya anak-anak tidak melihat hal tersebut sebagai sebuah tekanan untuk mereka, karena mereka memang harus menjalani protokol kesehatan saat mereka berada di rumah atau ketika harus keluar rumah. Anak-anak mengetahui, mereka harus mencuci tangan selesai beraktivitas dari luar rumah. Anak-anak belajar sekaligus beradaptasi dengan keadaan yaitu dimasa kenormalan baru menghadapi pandemi Covid19.

\section{Simpulan}

Hasil penelitian menyimpulkan bahwa anak memahami tentang virus Corona dan bahaya dari virus Corona. Selain itu, anak juga memahami bagaimana cara melindungi dirinya. Pemahaman anak, merupakan modal dasar untuk menumbuhkan kesadaran anak terhadap pentingnya penerapan protokol kesehatan dimasa kenormalan baru sebagai langkah preventif menjaga kesehatan diri di era new normal.

Hasil penelitian menunjukkan anak mampu melakukan asimilasi dan akomodasi tentang informasi Covid-19 dan mengakomodasi menjadi perilaku untuk beradaptasi di masa pandemic, sehingga secara fisik dan psikis kesehatan anak tetap terjaga di era new normal. Adapun cara yang dilakukan anak adalah dengan: 1) tetap berada di rumah/tidak keluar rumah/tidak keluar ke tempat umum, 2) mencuci tangan, 3) sekolah dari rumah, 4) berjemur/berpanas-panasan, 5) membunuh/ mematikan virus, 6) memakai masker, serta 7) menjaga jarak.

Melalui hasil penelitian ini diharapkan, orang tua mampu menjaga kesehatan anak-anak di era pandemi. Orangtua juga mampu menumbuhkan kesadaran anak tentang pentingnya protokol kesehatan sehingga mampu beradaptasi dengan baik yang ditunjukkan dengan adanya kemampuan memberikan rasa nyaman pada diri anak selama melakukan aktivitas dan kembali melakukan rutinitas belajar yang dilakukan secara daring. Sedangkan masyarakat disini dapat diasumsikan adalah lingkungan sekitar yang mendukung dan memberi penguat terhadap perilaku positif anak untuk mampu beraktivitas di era new normal dengan memberikan tontonan-tontonan positif yang mengedukasi mereka untuk tetap hidup sehat. Misalnya: tayangan iklan yang disajikan dalam bentuk kartun yang menarik. Saat anak-anak tertarik dengan tayangan yang disajikan di televisi, maka besar kemungkinan anak akan meniru. Selain itu, menumbuhkan kesadaran anak tentang pentingnya protokol kesehatan dapat dilakukan dengan menciptakan kegiatan yang menarik, seperti bercocok tanam, memelihara hewan, ataupun berwisata offline dengan membaca buku ensiklopedia. Dengan demikian, secara tidak langsung anak-anak sudah belajar untuk mengendalikan diri.

\section{DAFTAR PUSTAKA}

Afifah, N., M. (2020, Juni 5). Waspada, bahaya komplikasi infeksi virus corona pada anak. Retrieved from Kompas.com: https://health.kompas.com/read/2020/06/05/ 160400468/waspada-bahaya-komplikasi-infeksi-virus-corona-pada-anak?page=all.

Arnani, M. (2020, Maret 12). Timeline wabah virus corona, terdeteksi pada Desember 2019 hingga jadi pandemi global. Retrieved from Kompas.com: https://www.kompas.com/ tren/read/2020/03/12/113008565/timeline-wabah-virus-corona-terdeteksi-padadesember-2019-hingga-jadi?page $=$ all.

Baskara, B. (2020, April 18). Rangkaian peristiwa pertama covid-19. Retrieved from Kompas.com: https://bebas.kompas.id/baca/riset/2020/04/18/rangkaian-peristiwapertama-COVID-19/. 
Bogdan, R. C., \& Biklen, S. K. (1998). Qualitative research: An introduction to theory and methods (3rd ed.). Massachusetts: Allyn and Bacan.

Creswell, J. W. (2014). Research design: Qualitative, quantitative, and mixed methods approaches (4th ed.). California: Sage Publications.

Hoque, K. E., Kamaluddin, M. A., Razak, A. Z., \& Wahid, A. A. (2016). Building healthy eating habits in childhood: a study of the attitudes, knowledge and dietary habits of school children in Malaysia. PeerJ, 4, e2651. https://doi.org/10.7717/peerj.2651

Ihsani, N., Kurniah, N., \& Suprapti, A. (2018). Hubungan metode pembiasaan dalam pembelajaran dengan disiplin anak usia dini. Jurnal Ilmiah Potensia, 3(2), 105-110.

Kompas Online. (2020, Maret 09). Di tengah kekhawatiran soal wabah virus corona, bagaimana agar tak panik? http://www.kompas.com.

Moleong, L, J. (2017). Metode penelitian kualitatif. Bandung: Remaja Rosdakarya.

Nisa, M. K. (2016). Studi tentang daya tangguh (resiliensi) anak di panti asuhan sidoarjo. Jurnal BK Unesa, 6(3).

Patilima, H. (2013). Peran pendidik pos PAUD dalam membangun resiliensi anak. Jurnal Pendidikan Usia Dini,7 (1), 173-194.

Prianti, D. D. (2011). Studi fenomenologi tentang pengalaman komunikasi antar pribadi orang tua anak-anak terhadap pemahaman anak pada norma-norma perilaku (Kasus pada anak penyandang autisme). Jurnal Ilmiah Komunikasi Makna, 2 (1), 1-8.

Rahardjo, W., Qomariyah, N., Mulyani, I., \& Andriani, I. (2020). Social media fatigue pada mahasiswa di masa pandemi COVID-19: Peran neurotisisme, kelebihan informasi, invasion of life, dan kecemasan. Jurnal Psikologi Sosial. Retrieved from http://jps.ui.ac.id/index.php/jps/article/view/220.

Santrock, J.W. (2007). Perkembangan anak, edisi 11, jilid 1. Jakarta: Erlangga.

Solso, R. L. (2008). Psikologi kognitif. Jakarta: Erlangga.

Spradley, J. P. (1980). Participant observation. New York: Holt, Rinehart and Winston.

Sugiyono (2009). Metode penelitian pendidikan pendekatan kuantitatif, kualitatif, dan R\&D. Bandung: Alfabeta.

Watt, J. H., \& Berg, S. A. V. (1995). A research methods for communication science. Boston: Allyn and Bacon.

Wulan, A. (2020, Mei 28). Makna new normal di tengah pandemi viris corona covid-19. Retrieved from Liputan6.com: https://www.liputan6.com/bola/read/4265522/ makna-new-normal-di-tengah-pandemi-virus-corona-COVID-19.

Winarni, M. (2005). Dukungan sosial orang tua terhadap anak dalam belajar ditinjau dari tingkat pendidikan orang tua. Jurnal Psikologi, 1 (1). Retrieved from https://ejournal.up45.ac.id/index.php/psikologi/article/view/39. 